\title{
Social Innovations in Music Education: Creating Institutional Resilience for Increasing Social Justice
}

\author{
Lauri Väkevä \\ Sibelius Academy of the University of the Arts Helsinki, Finland \\ Heidi Westerlund \\ Sibelius Academy of the University of the Arts Helsinki, Finland
}

\author{
Leena IImola-Sheppard \\ International Institute for Applied Systems Analysis Laxenburg, Austria
}

This article addresses the discourse on social justice and inclusion in music education by exploring how educational systems can be transformed in the rapidly changing world of late modernity. We aim to show that one possible approach to tackling injustice in music education at the micro level is to reflect on the possibilities for institutional change at the macro level. As an institutional context, we use Basic Education in the Arts, a characteristically Finnish system of extracurricular arts education. With the help of systems analysis and a case from the Arts as Public Service: Strategic Steps towards Equality (ArtsEqual) research project, we aim to show that the resilience of a music education system can be supported by institutional innovations that help to redefine the system's purpose and identity and make its boundaries more flexible. Our case study, the Flora project, suggests that institutional innovation can lead to new insights on how social justice and inclusion may be enhanced within a music education system by opening its borders to the exchange of new information and resourcing options. However, to grasp the full import of such initiatives requires that policy makers and institutional leaders understand the need to reflect critically on the possibilities of institutional change, recognizing the important role that operators within the system can play in such change.

Keywords: music education, resilience, social innovation, systems analysis, social system, social justice

(C) Lauri Väkevä, Heidi Westerlund, and Leena Ilmola-Sheppard 2017. The content of this article is the sole responsibility of the author. The ACT Journal and the Mayday Group are not liable for any legal actions that may arise involving the article's content, including, but not limited to, copyright infringement. 
$\mathrm{T}$ his article addresses the discourse on social justice and inclusion in music education by exploring how educational systems may be transformed in the rapidly changing world of late modernity. Ruth Wright $(2015,341)$ argues that access to music education requires access to the cultural "code" that "is never overtly taught during the education process ... It has to be learned in the home and is not found in all homes. Children of more socially advantaged groups tend to acquire the code, whereas their less advantaged peers do not." Wright suggests that music educators ought to pay attention to the micro level interactional processes between students and teachers as a key to understanding how this code influences access to music education. Whilst agreeing with Wright, we suggest that an alternative, and equally necessary, approach to tackling injustice in music education is to reflect on the possibilities for institutional change at the macro level produced by social innovations that build institutional resilience.

By social innovations we refer to efforts "to design initiatives in a particular part of society-an organisation, a practice, or an area of activitythat signal a promising path of wider social change even as they meet a pressing need," and that seek "to advance convert experiments designed to solve social problems into transformative ambition" (Mangabeira Unger 2015, 233). Such innovations may also be described as catalytic events that provide new conditions for understanding the social system and its operations. Institutional resilience is here understood as a counterforce to "the paradox of the modern age," the organizational silo effect (Tett 2015) in which the institutional system blindly pursues its purpose and social reproduction, favouring some and excluding others, and in this way reproduces social injustice. It can be argued that in the rapidly changing conditions of late modernity (Giddens 1990, Bauman 2000), it is vitally important to find ways to avoid the detrimental effects of the silo effect; arguably, this also applies to music education, where institutional change and interpenetration between social systems may be required to open the doors to marginalized or otherwise excluded individuals and groups (Münch 1988, Sevänen 1998, Väkevä 2015).

In this article, we use systems analysis ${ }^{1}$ to explore the macro level processes of music education and the role of social innovations in creating institutional resilience-or the institution's "ability to cope with and adapt to external pressures" (Sjöstedt 2015, 22)-in the Finnish context. Our study is part of the Arts as Public Service: Strategic Steps towards Equality (ArtsEqual) research project, which responds to The Committee for the Future

Lauri Väkevä, Heidi Westerlund, and Leena Ilmola-Sheppard. 2017. Social innovations in music education: creating institutional resilience for increasing social justice. Action, Criticism, and Theory for Music Education 16 (3): 129-47. doi:10.22176/act16.3.129 
of the Parliament of Finland's call to encourage a nationwide rethinking of its public services, including "schools, health centres, and other public organisations" (Tulevaisuusvaliokunta 2014). The project also responds to the recent recommendation (Ilmola and Casti 2014) to invest in culture and social capital as a means to maintain Finnish citizens' commitments to society, especially in dire economic times. Funded by the Strategic Research Council of the Academy of Finland, with over 70 part-time and full-time researchers, ArtsEqual has set for itself the goals of identifying the mechanisms that produce inequality in arts and arts education services in Finland, and facilitating research interventions that increase equality and participation within the system (for more details, see http://www.artsequal.fi). Taking the intra-institutional challenges under scrutiny, the project also aims to widen the perspective beyond the current institutional silos. The research in ArtsEqual is organised through numerous case studies that address a variety of perspectives of inequality (e.g. gender, cultural rights, regional access, students with special needs, and life-long learning), and many of the studies deal with new ideas on how institutional resilience may be built through social innovations-or, more specifically, institutional innovations that aim to harness new social structures to generate new social values and outcomes (Nicholls, Simon, and Gabriel 2015, 3).

\section{Context: Music education in Basic Education in the Arts}

The Finnish educational system has two primary contexts in which music is taught to minors: (1) music education in the comprehensive school and postcompulsory secondary school and (2) extracurricular music education. These contexts differ in many respects: while the core of music education in comprehensive and post-compulsory secondary school is based on mandatory lessons targeted for the whole age class with optional electives, extracurricular music education serves selected groups of students who want to study in music institutions or such general adult education institutions as folk high schools (Korpela et al 2010, Väkevä 2015).

The specific context of our analysis is Basic Education in the Arts system (Taiteen perusopetus, henceforth BEA). BEA is a characteristically Finnish approach to extracurricular arts education, only partly comparable to publicly funded schemes of extracurricular art education in other countries, such as the cultural school system in Sweden (Heimonen 2002). Primarily targeted at 
minors, BEA offers tuition in music, dance, theatre, visual and audiovisual arts, crafts, architecture, literary arts, and even circus performance through a wide network of art schools and institutes distributed across the country. While BEA is promoted as an educational system in its own right, and has its own legal basis of regulation (Laki taiteen perusopetuksesta 21.8.1998/633), it is intended to supplement the arts education provided by comprehensive schools. Thus, music education in the BEA can be seen as a specific subsystem of the Finnish music education system that has its own goals, contents, pedagogical approaches, and principles of assessment (Korpela et al 2010, Väkevä 2015).

Unlike comprehensive education, participation in the BEA is voluntary, and its providers may "charge moderate fees" (OKM 2015). Local authorities that provide BEA receive funding from the Government based on the number of inhabitants of their municipality (OKM 2015). In addition, some providers of BAE receive discretionary Government grants based on the confirmed number of lessons given (OKM 2015). Receiving such discretionary funding requires approval from the Ministry of Education and Culture. A limited number of such approvals are granted each year, based on the quota of teaching hours allocated in the yearly Government budget. In order to receive approval and the full public subsidy, an institution has to fulfil the quality standards set by the Ministry (Taiteen perusopetuksen järjestäjän muistilista 2013).

Similar to arts education in comprehensive schools, the BEA is guided by the national core curriculum. The BEA curriculum is divided into an advanced syllabus (laaja oppimäärä, Opetushallitus 2002) and a basic syllabus (yleinen oppimäärä, Opetushallitus 2005). There are differences between these syllabi in terms of the maximum amount of lessons available, the general goals and contents of the studies, and how the students should be assessed. The advanced syllabus guarantees the students almost three times the amount of lessons compared to the basic syllabus ( 1300 vs 500 lessons). ${ }^{2}$ The advanced syllabus also offers a more structured and goal-directed study path towards secondary level studies. In turn, the basic syllabus builds on more flexible study opportunities where the student can choose among various study modules (OPH 2008).

Recent reports testify that music is the most popular BEA subject in terms of both supply and demand. In the year 2007-08, over 180 publicly funded music schools were operative in Finland, providing goal-oriented music 
tuition to approximately 67000 students (Koramo 2009, 14, 18).3 In 2012, $54 \%$ of all BEA students were studying music (Taiteen perusopetuksen alueellinen saavutettavuus 2012, 2014, 34). In 2007-08, 84.5\% of all lessons in BEA were music lessons (Koramo 2009). It is the advanced syllabus that is usually associated with extracurricular music education, providing the latter a unique profile apart from school music and, to a degree, from other arts subjects in the BEA. Of the music institutions that received discretionary grants from the Government in 2007-08, almost all (98.9\%) focused on teaching along the advanced syllabus (12). In turn, $66 \%$ of all students following the advanced curriculum studied music in 2012 (Taiteen perusopetuksen alueellinen saavutettavuus 2012 2014, 34).

What is the reason for the prominence of the advanced music syllabus in the BEA? It has been suggested that this is a result of the public funding mechanism:

The state share based on the amount of the lessons is tied to realization of the advanced syllabus in music. Because of this, [music] teaching according to the basic syllabus is provided mainly by institutions of liberal adult education [vapaa sivistystyö] and private enterprises (that operate without public funding) (Tiainen et al. 2012, 101, our translation).

Music education in the BEA thus seems to be based on the premise that statelevel public funding should primarily support the kinds of musical studies that reflect the values of the advanced syllabus. This policy produces a system dynamics where music education in the BEA deviates from music education in other basic education level institutions (comprehensive schools and liberal adult education institutions) and the BEA in other arts subjects, the default expectation being that music is most effectively studied by proceeding from level to level according to a curricular scheme inherited from the European music school tradition. The reduced amount of lessons and the more flexible study options of the basic syllabus are not judged to be sufficient to fulfil the quality expectations in this scheme. Arguably, such system dynamics influence who gets to study music in the BEA, how, and on whose terms.

Several other factors are also reported to influence access to musical studies in the BEA. It has been estimated that c. $90 \%$ of all music lessons within the BEA focus on Western classical music (Kiuttu 2008, Pohjannoro 2009, Kurkela and Väkevä 2012), which is obviously connected to the heavy emphasis on the European music school instruction model, and the corollary expectation that one-to-one instrumental tuition should be at the core of 
extra-curricular music education. Moreover, the majority of the music students in the BEA are female (c. $75 \%$ in 2012; see Taiteen perusopetuksen alueellinen saavutettavuus 2012 2014, 34). Social-economic factors also seem to influence who gets to study music in the BEA: a recent report from the Cultural Office of the City of Helsinki suggests that neighbourhoods with higher socioeconomic standards of living provide better opportunities for children and young people to apply to BEA music studies (Vismanen, Räisänen, and Sariola 2016). There are also differences in the regional supply of services: even if the network of music schools and institutes is extensive, remote areas offer fewer study possibilities than densely populated areas, reflected for instance in the selection of instruments available to study and longer distances between home and the BEA institution (Tiainen et al. 2012). It also seems that it is more difficult to gain admission to music programs in densely populated municipalities, and the tuition fees tend to be higher in such municipalities because of the higher office rents. Recently, an additional need has emerged to consider how the present system can provide goaloriented arts education services for groups that have been marginalised from such services, such as the rapidly growing group of elderly people (Laes 2015), cultural minorities (Kallio 2016), or students with special education needs (Koivula and Merimaa 2006).

All in all, it can be argued that music education in the BEA is path dependent. The historical development of the Finnish system of music education has generated a structure that shapes the students' access to extracurricular musical studies and affects the relationship between supply and demand through public regulation. Arguably, this structure produces mechanisms that influence equality within BEA music education, making it a special case to consider in terms of social justice as part of the Finnish music education system.

\section{Research objective and methodological approach}

In what follows, we will analyse Finnish music education as a social system beyond the micro level teacher-student interactive dyad. Examined as a macro level complex of interactions and organizations, a social system may be understood as a configuration of structures and processes where the system's purpose regulates its functions and makes them meaningful in a given social setting, defining its boundaries (Luhmann 1995). Such systems are 
characterized by the constant need to maintain the purpose and identity that distinguish them from other systems (Berger and Luckmann 1966; Luhmann 1995). The purpose and identity of a social system are generated in an intersubjective process of communication that is largely autopoietic, or selfmaintaining, self-supporting, and self-reproducing (Maturana and Varela 1991). Autopoiesis necessitates selectivity: a social system filters outside information and resources that support its identity and purpose (Weick 1995). This selection process maintains the system by producing conditions for justifying its meaningfulness. In this framework, music education systems are not seen as mechanistic aggregates of parts in isolable causal relations, but rather as organic wholes of subsidiary components. Yet, such systems can also include subsystems that may have their own justificatory discourses and mechanisms of autopoiesis (Laszlo 1996, 10).

Against this theoretical starting point, we argue that, when considered as a social system, music education should not only aim to fulfil its perceived purpose and to maintain itself, but also to co-evolve as a part of the society. In order to do so, it should develop a resilience towards the rapid and complex societal and cultural changes characteristic of late modern society (Giddens 1990, Bauman 2000). We also argue that, as a social system that has mechanisms and capabilities for critical thinking and praxis, it is in a better position to generate resilience.

More specifically, in our systems analysis we aim to illustrate how the boundaries of a social system can change based on how its purpose is understood in relation to the society, and how such change is essential in increasing the system's resilience. We also attempt to show that such an increase in resilience is necessary for providing the conditions for social justice and equality for all social systems.

With these goals in view, we will present three qualitative system maps, or models, that facilitate the detection of those features that dominate the behaviour of music education in Finland, and argue why institutional innovations can change the way it sees its purpose and identity (see Forrester 1968, 2007; Checkland 1981, 1999; Meadows 2009). In line with the social systems framework (Luhmann 1995), we do not claim that such models represent reality per se; rather, they should be understood as mental representations that help us to understand system behaviour (Hodgkinson 2003, Berger and Luckmann 1966), arrived at through negotiation in a professional discourse (Checkland 1999), in this case facilitated by a systems

Lauri Väkevä, Heidi Westerlund, and Leena Ilmola-Sheppard. 2017. Social innovations in music education: creating institutional resilience for increasing social justice. Action, Criticism, and Theory for Music Education 16 (3): 129-47. doi:10.22176/act16.3.129 
analysis scholar who also belongs to the writing team of this article. Such models are primarily useful as heuristic aids: they help us to develop new ideas of how social systems may transform themselves in order to better adapt to the changing operational environment by developing resilience and enhancing institutional learning (Senge 2006).

We will illustrate the emergence of resilience in the BEA through an example taken from the ArtsEqual case studies. The focus of this case study is on the Flora project (Floora-hanke), a music education initiative that aims to make extracurricular music education more accessible to at-risk students (Kamensky and Rechardt 2016). Supported by Finnish Ministry of Education and Culture, Regional State Administrative Agencies, City of Helsinki Cultural Office, and several Finnish foundations, Flora was initiated by a group of instrumental teachers at the capital region of Finland who wanted to improve the situation of unequal access to BEA music lessons, especially as concerns children from disadvantaged families. In order to reach such families, the teachers created a network between the social workers in the municipalities and the student services of the partner music institutions. They also formed partnerships with local comprehensive schools that offered free teaching premises for the project. The students were chosen by social workers, rather than by the teachers. Currently, approximately 160 students in a variety of municipalities have been offered the opportunity to study music without having to pay or to participate in entrance tests. Many of these students are boys, and many share an immigrant background. Some of them have also decided to continue their studies in the advanced syllabus programs or secondary level institutions.

It could be argued that, while such initiatives as Flora are important, they do not belong to the realm of BEA music studies, even if they can open paths into it. However, we would like to argue that such interventions can support the institutional innovation of the BEA, as they introduce diversification of the supply of the music education services and thus increase resilience within the music education system as a whole (see Ilmola and Strelkovsky 2016). In this way, the system can better address the demands presented by rapidly diversifying and increasingly complex society, such as the challenges posed by increasing immigration, economic inequality, the widening sustainability gap, neglect of the cultural needs of ethnic minorities, and the gendering of the cultural field. However, this necessitates that music education providers must both identify such challenges and be ready to adapt to the societal changes. In 
turn, this necessitates a readiness for institutional learning (Senge 2006) and a political will to redefine the purpose and identity of the system when needed. Such a redefinition of system purpose and identity also influences the way the system is delimited, which in turn may affect its public regulation. Such projects as Flora can thus be interpreted as interventions that make the borders of the Finnish music education system and its subsystems (such as music education in BEA) more flexible, opening new channels for resourcing, and thus increasing access to the system for individuals and groups that have been previously marginalized.

\section{Three models of BEA as a social system with purpose}

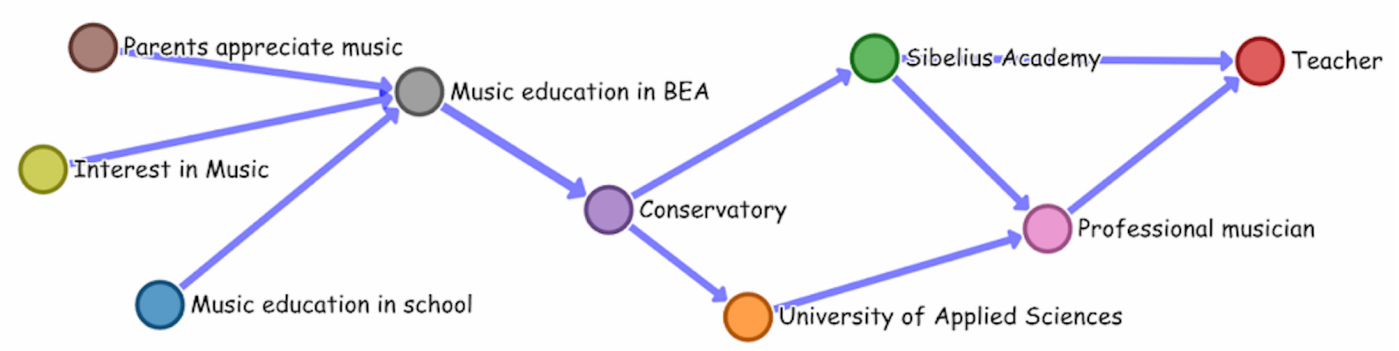

Figure 1. Linear model of Finnish music education system

Figure 1 displays a simplified version of how music education in the BEA relates to other Finnish systems of music education, and what factors influence the selection of new students. The figure depicts the BEA's role in supporting musical career paths in the present system. Obviously, the shared perception that led to selecting these components and interactions and excluding others reflects the ideal that music education in the BEA should provide all students with a sound basis for applying to professional study programs, even if many of them would not in fact continue their studies in secondary education. As discussed above, emphasising the career-oriented study path may be seen as a key aspect beneath the political will to support the BEA music institutions that organise extracurricular music education along with the advanced syllabus. The emphasis is also visible in our choice to include school music education, despite its own curriculum-driven distinct purposes, as one of the factors that help to select students for BEA music institutes. From this perspective, a key task of the school music educator is to find potential talent and inform the most talented about the possibilities to 
study in the BEA in order to proceed to musical careers. While obviously simplified, the model brings forth one important aspect of the Finnish music education system that gains in importance when considering the regulation policy of music education in the BEA.

The model in Figure 1 may also be read as a display of connections between some of the factors that influence who gets to study music in the BEA, how, and on whose terms. You may observe that in this representation, the music teacher-wherever she works-is seen as an outcome of the career path, rather than an active, critical change agent. The linearity of the model shows the teacher's role in sustaining the purpose of the system by working in the institutions within the music education system, neglecting the transformative work teachers can do across the institutions. Importantly, in this simplified model, the music education system has no other connections with society other than being resourced on the basis of selecting the musically talented in the population, providing the optimal conditions for training professionals, and leaving the roles of connoisseur audience member and educated amateur to those who do not continue their studies in secondary or tertiary level institutions. In this model, the music teacher is a key link in the feedback loop that maintains the status quo of the whole system, realising the strong selection function necessary for differentiation of professions in modern society.

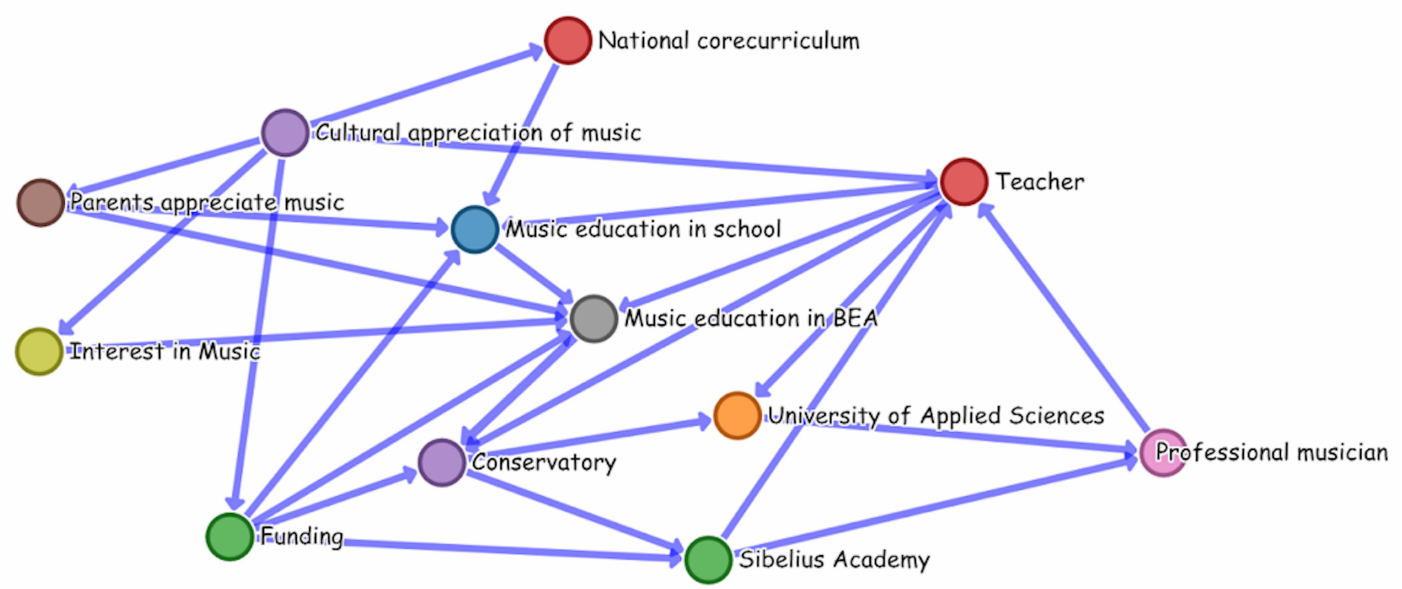

Figure 2. Systems model of Finnish music education with teachers as change agents

The second model, displayed in Figure 2, has some added nodes, such as the criteria for funding and the national core curriculum. This systems map illustrates the important role that teachers can play in institutional change: 
they can have an impact on all educational levels, not just in training future professionals. In other words, new feedback loops emerge within the system model: we are now able to see how the teachers can work across the whole sector, influencing all parts of the system and opening new paths for information exchange and resourcing between the subsystems.

Compared to the previous model, this systems map addresses the role of teachers as important change agents that both sustain the stability of the system but also provide a key to its transformation and development. It is in the pedagogical and administrative transactions facilitated by the teachers that the micro level interactional processes that can change the pattern of social reproduction are located (Wright 2015). Importantly, however, teachers may also be seen as sources of the whole system's resilience, operating at the macro level of institutional innovation. This was clearly manifest in the case of Flora, as the project was planned and led by a music teachers working together for institutional change.

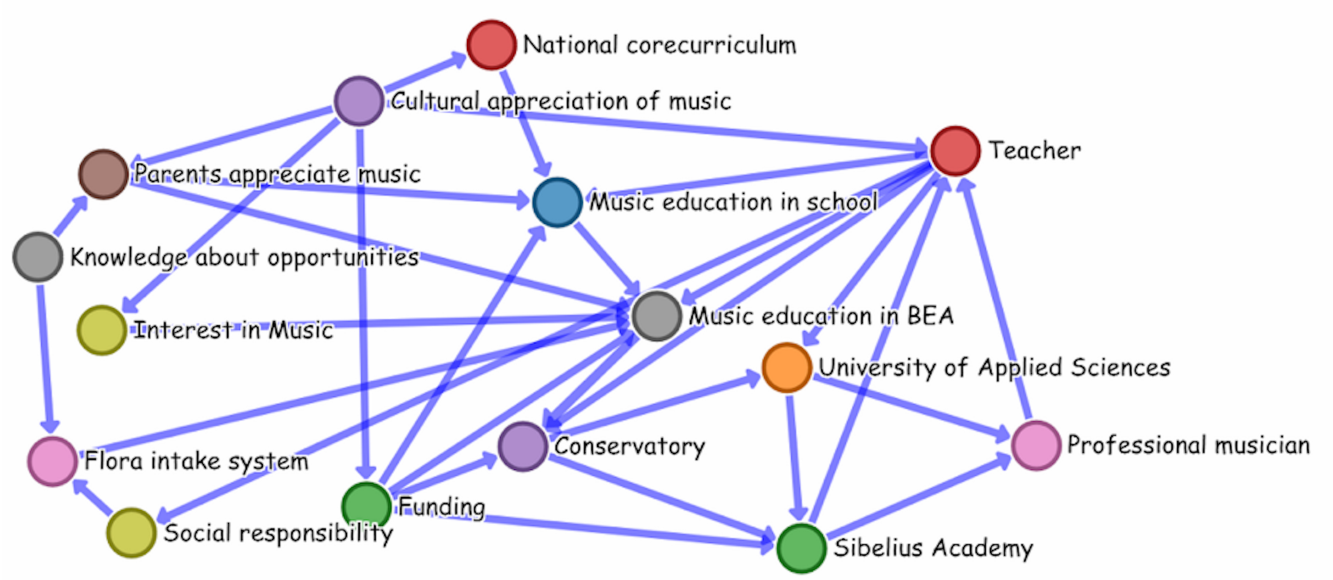

Figure 3. Systems model of Finnish music education with the catalytic case of Flora added

The third model presents the same systems map after adding one catalytic event that potentially produces institutional learning: Flora project. Adding Flora to the model also inspired us to expand the previous network of nodes and their connections. We now recognize that the parents' appreciation of and their children's interest in music may not be the only, nor even the defining factors that influence who gets to study music in the BEA, how, and on whose terms. One added element-the parents' knowledge of the available study opportunities-seems to be an especially potential determinant within which 
Flora specifically invests. While the BEA also offers tuition free of charge for those with economic difficulties, this option is not widely advertised and seems to be used sparingly. Thus, families from lower socio-economic or immigrant backgrounds may not even know about the possibility for their children to study music in the BEA.

From the perspective of social justice, Flora may be interpreted as an institutional effort to narrow the opportunity gap for some children. In the North American context, Robert Putnam $(2015,176)$ has shown that the poor socio-economic status of the family is likely to widen the opportunity gap, more so than the talent or innate potential of the child. Putnam's large study shows that the opportunity gap in early life significantly decreases chances to improve children's lot in life. Poor children are three times more unlikely than their non-poor classmates to participate in extracurricular activities. However, the opportunity gap may also be an effect of the system behaviour, reflecting its internal justification mechanisms. For instance, in Ontario, Canada, extracurricular "music education serves on average $10 \%-12 \%$ of secondary school students, once they complete compulsory music education at the age of 14" (Wright 2015, 343). One of the explanations for this may be that "teachers and administrators serve as gatekeepers to slots in extracurricular activities, recruiting students they perceive to be talented while restricting others who are disqualified by academic standards" (McNeal, Jr. cited in Putnam 2015, 178). In this way, as Wright (2015) puts it:

education plays a trick on the less advantaged members of society. By wrapping education within a cultural code familiar to those from dominant sectors of society, the children of these dominant social groups are predisposed to understand and benefit from education before their less advantaged peers. (345)

Importantly, this exclusion can even lead into the self-exclusion of the students (or their families) if they recognise themselves as "non-elite," acknowledging the rules of this particular game of power and recognizing that "they are unlikely to win it" (Wright 2015, 345).

While Finnish society is in many ways different from North American society, structural institutional innovations such as including the social sector in the mechanism that selects the students for extracurricular music education may highlight local ways to fight against the detrimental outcomes of the widening standard-of-living gap that plagues post-industrial societies. In this sense, the Flora project may be seen as a social investment and institutional 
innovation, as it suggests a new way of cooperating in late modern society (Mangabeira Unger 2015, 234). More specifically, Flora

- helps us to identify a problem that cannot be solved by the conventional practices within the music education system,

- exemplifies, through a practical initiative, a new way of understanding the problem and of dealing with it, and

- suggests a path for reform.

Thus, Flora also helps to redefine the purpose of music education, rather than simply relying on the professional career model. Although the redefinition of the music education system does not necessarily have any direct consequences for the pedagogies or repertoires that teachers use, the recognised social responsibility of music education widens the understanding of its societal role, and helps us to consider inclusion as one important criterion for increasing the quality of the system. In this way, it might also suggest new means to judge the value criteria of public regulation.

\section{Concluding thoughts}

Social regimes are organised to reproduce themselves. If they allowed no room for their own shaping, social innovation would be impossible-except through individual and collective rebellion, in the favouring circumstance of crisis. If they had done much more to open themselves to challenge and change than they have, social innovation might be unnecessary (Mangabeira Unger 2015, 234).

We argue that such social innovations as the Flora project are necessary in order for institutional music education to create resilience and better serve the whole population in these times of rapid societal change. As a social innovation, Flora can further enhance institutional learning (Senge 2006), as it highlights some of the mechanisms that produce inequality in Finnish music education and demonstrates one practical way to diminish their power. It is our belief that such practices as Flora may act as catalysts for fostering resilience and institutional learning, thus influencing the system as a whole.

In this article, we have aimed to show that one possible approach to tackling injustice in music education at the micro level is to reflect on the possibilities for institutional change at the macro level. We believe that macro level systemic mappings, such as the one produced in this study, can provide heuristic aids for a holistic understanding of the relationships, boundaries, and dynamics within music education. Importantly, systems analysis can 
serve as a tool to reflect on the purpose and identity of a social system in relation to the wider society. With the aid of systems thinking (Meadows 2009), such catalytic practices as Flora can be better understood in relation to the whole music education field. Flora helps us to rethink the boundaries and practices of the music education system by changing the conditions through which we may think about and act upon it, in this case by pointing out new possibilities in the BEA music education subsystem, and, thus, new ways to judge the social value of the system. As discussed above, due to historical factors the definition of the purpose and identity of this subsystem has been largely based on a professional ethos that has influenced its public funding policy, its curricular choices, and how access to it is granted. Systems analysis can offer a platform for heuristic analysis that can in turn provide insights for exploring future changes, and generating new ideas and new catalytic practices within this historically developed framework. In this way, we believe that research that uses systems analysis as an aid can support school leaders, policy makers, and politicians in making decisions concerning the future of music education in Finland.

\section{Acknowledgments}

This publication has been undertaken as part of the ArtsEqual project, funded by the Academy of Finland's Strategic Research Council from its Equality in Society programme (project no. 293199)

\section{About the Authors}

Lauri Väkevä is the vice-rector responsible of research and doctoral education at University of Arts Helsinki and a professor in music education at Sibelius Academy of the University of the Arts in Helsinki. A co-author of three books, he has also published several book chapters and numerous articles in peerreviewed journals, as well as presented papers in international conferences in the fields of music education, musicology, music history and popular music studies. His main research interests cover Afro-American music, popular music pedagogy, history of popular music, pragmatist aesthetics, philosophy of music education, informal learning, digital music culture, educational systems and history of education. Aside of academic career, his work assignments have covered working as a musician, music journalist, general music teacher, and instrumental teacher. Email: lauri.vakeva@uniarts.fi 
Heidi Westerlund is a professor at the Sibelius Academy, University of the Arts Helsinki, Finland, where she is also responsible for the music education doctoral studies. She has published widely in international journals and books and she is the co-editor of Collaborative learning in higher music education (Ashgate) as well as the Editor-in-chief of the Finnish Journal of Music Education. Her research interests include higher arts education, music teacher education, collaborative learning, cultural diversity and democracy in music education. She is currently leading two research projects funded by the Academy of Finland: The arts as public service: Strategic steps towards equality (2015-2020) and Global visions through mobilizing networks: Co-developing intercultural music teacher education in Finland, Israel and Nepal (2015-2019). Email: heidi.westerlund@uniarts.fi

Leena Ilmola-Sheppard is a Senior Research Scholar in the Advanced Systems Analysis (ASA) Program. She was previously Project Manager in the Game Changers and the Global Economy 2030 project Seven Shocks Projects for Scotland, Finland and Korea. Her research theme is uncertainty and resilience of social systems. She is developing new modeling methods for foresight and tools for pragmatic decision making. Her current projects include developing management systems for resilience. Dr. Ilmola-Sheppard is Scientific Coordinator of the Global X-Network (GXN). Dr. Ilmola-Sheppard is also currently working as an expert for the Futures Committee of the Finnish Parliament (since 2013) and previously worked for the Prime Minister's Office for the Finnish Government's Futures Review process (2012-2014). Since 2005, she has been a member of the Board of the Finnish Futures Association. Email: ilmola@iiasa.ac.at

\section{References}

Bauman, Zygmunt. 2000. Liquid modernity. Cambridge: Polity.

Berger, Peter L. and Thomas Luckmann. 1966. The social construction of reality: A treatise in the sociology of knowledge. New York: Doubleday Anchor Books.

Checkland, Peter B. 1981. Systems thinking, systems practice. Chichester: John Wiley \& Sons.

Checkland, Peter B. 1999. Systems thinking. In Rethinking management information systems: An interdisciplinary perspective, edited by Wendy Currie and Bob Galliers, 45-56. New York: Oxford University Press.

Forrester, Jay W. 1968. Industrial dynamics-after the first decade. Management Science 14 (7): 398-415.

Lauri Väkevä, Heidi Westerlund, and Leena Ilmola-Sheppard. 2017. Social innovations in music education: creating institutional resilience for increasing social justice. Action, Criticism, and Theory for Music Education 16 (3): 129-47. doi:10.22176/act16.3.129 
Forrester, Jay W. 2007. System dynamics-the next fifty years. System Dynamics Review 23 (2-3): 359-70.

Giddens, Anthony. 1990. The consequences of modernity. Stanford: Stanford University Press.

Heimonen, Marja. 2002. Music education \& law: Regulation as an instrument. Studia Musica 17. Helsinki: Sibelius-Academy.

Hodgkinson, Gerard P. 2003. The interface of cognitive and industrial, work and organizational psychology. Journal of Occupational \& Organizational Psychology 76 (1): 1-25.

Hordjiik, Leen. 2007. What is systems analysis? Options Magazine, Winter 2007.

http://www.iiasa.ac.at/web/home/about/whatisiiasa/whatissystemsanaly sis/what_is_systems_analysis.html

Ilmola, Leena, and John Casti. 2014. Hyvinvointiyhteiskunta 203o. Helsinki: Eduskunnan tulevaisuusvaliokunnan julkaisuja 2/2014.

Ilmola, Leena, and Nikita Strelkovsky. 2016. Soft social systems and shocks: An experiment with an agent based model. In Applications of systems thinking and soft operations research in managing complexity, edited by Anthony J. Masys, 269-90. Dodrecht: Springer.

Kallio, Alexis A. 2016. Navigating (un)popular music in the classroom: Censure and censorship in an inclusive, democratic music education. Helsinki: Sibelius Academy of the University of the Arts Helsinki. Studia Musica 65.

Kamensky, Hanna and Rechardt, Päivi. 2016. Educating beyond success in music schools. Paper presented at Kasvatustieteen päivät conference, Turku, Finland, November 17, 2016.

Kiuttu, Outi. 2008. Rytmimusiikki ja vapaa säestys taiteen perusopetuksessa 2007. Finnish Journal of Music Education 11 (1-2): 119-21.

Koivula, Pirjo, and Erkki Merimaa. 2006. Onko erityisopetukseen liittyvä normisto sitä, mitä kirjoitetaan, luetaan vai tulkitaan? EriKa: Erityisopetuksen tutkimus-ja menetelmätieto 2: 8.

Koramo, Marika. 2009. Taiteen perusopetus 2008. Selvitys taiteen perusopetuksen järjestämisestä lukuvuonna 2007-2008. Helsinki: Opetushallitus. http://wwww.oph.fi/download/46516_taiteen_perusope tus_2008.pdf 
Korpela, Pia, Anna Kuoppamäki, Tuulikki Laes, Laura Miettinen, Sari Muhonen, Minna Muukkonen, Hanna Nikkanen, Aleksi Ojala, Heidi Partti, Timo Pihkanen, and Inga Rikandi. 2010. Music education in Finland. In Mapping the common ground: philosophical perspectives on Finnish music education, edited by Inga Rikandi, 14-31. Riga: BTJ Finland.

Kurkela, Vesa, and Lauri Väkevä. 2012. Rhythm masters. Developing a master program in popular music and folk music in provincial areas in Finland. US-China Education Review B 2: 244-57.

Laes, Tuulikki. 2015. Empowering later adulthood music education. A Case study of a rock band for third age learners. International Journal of Music Education Resarch 33 (1): 51-65.

Laki taiteen perusopetuksesta 21.8.1998/633. https://www.finlex.fi/fi/laki/ ajantasa/1998/19980633

Laszlo, Ervin. 1996. The systems view of the world. A holistic vision for our time. Cresskill: Hampton Press.

Luhmann, Niklas. 1995. Social systems. Stanford: Stanford University Press.

Maturana, Humberto R., and Fransisco J. Varela. 1991. Autopoiesis and cognition: the realization of the living. Dodrecht: Springer.

Meadows, Donella H. 2009. Thinking in systems: A primer. New York: Earthscan.

Mangabeira Unger, Roberto. 2015. Conclusion: The task of the social innovation movement. In New frontiers in social innovation research, edited by Alex Nicholls, Julie Simon, and Madeleine Gabriel, 233-51. New York: Palmgrave.

Münch, Richard. 1988. Understanding modernity. Towards a new perspective going beyond Durkheim and Weber. London: Routledge \& Kegan Paul.

Nicholls, Alex, Julie Simon, and Madeleine Gabriel. 2015. Introduction: Dimensions of social innovation. In New frontiers in social innovation research, edited by Alex Nicholls, Julie Simon and Madeleine Gabriel, 126. New York: Palmgrave.

OKM. 2015. Taiteen perusopetus. http://www.okm.fi/OPM/Koulutus/ perusopetus/taiteen_perusopetus/?lang=fi 
OPH. 2008. Taiteen perusopetuksen käsite, rakenne ja laajuus. Opetushallitus. Tiedote 16/2008. http://www.oph.fi/download/110889_ tpo_tiedote_16_2008_suom.pdf

Opetushallitus. 2002. Taiteen perusopetuksen musiikin laajan oppimäärän opetussuunnitelman perusteet 2002. http://www.oph.fi/download/ 123013_musiik_tait_ops_2002.pdf

Opetushallitus. 2005. Taiteen perusopetuksen yleisen oppimäärän opetussuunnitelman perusteet 2005. http://www.oph.fi/download/ 123012_taideyl_ops.pdf

Pohjannoro, Ulla. 2009. Näkymiä musiikkiopistojen tulevaisuuteen. In Muusikko eilen, tänään ja huomenna. Näkökulmia musïkkialan osaamistarpeisïn, edited by Minna Muukkonen, Mirka Pesonen and Ulla Pohjannoro, 10-23. Helsinki: Sibelius-Akatemian selvityksiä ja raportteja 13/2011.

Putnam, Robert. 2015. Our kids: The American dream in crisis. New York \& London: Simon \& Schuster.

Senge, Peter M. 2006. The fifth discipline: The art and practice of the learning organization. London: Random House.

Sevänen, Erkki. 1998. Taide instituutiona ja järjestelmänä. Modernin taideelämän historiallis-sosiologiset mallit. Helsinki: Suomalaisen Kirjallisuuden Seura.

Sjöstedt, Martin. 2015. Resilience revisited: Taking institutional theory seriously. Ecology and Society 20 (4). https://www.ecologyandsociety. org/vol20/iss4/art23/

Taiteen perusopetuksen alueellinen saavutettavuus 2012. 2014. Helsinki: Etelä-Suomen aluehallintoviraston julkaisuja 28/2014. http://www.avi.fi/ documents/10191/52019/Taiteen+perusopetuksen+alueellinen+saavutett avuus+2012/04fff831-7505-4d85-96bf-cof3bd9ff8ed

Taiteen perusopetuksen järjestäjän muistilista. 2013. http://www.artsedu.fi/ easydata/customers/tpo/files/demo/muistilista_taiteen_perusopetuksen jarjestamisesta.pdf

Tett, Gillian. 2015. The silo effect. Why every organisation needs to disrupt itself to survive. London: Abacus.

Lauri Väkevä, Heidi Westerlund, and Leena Ilmola-Sheppard. 2017. Social innovations in music education: creating institutional resilience for increasing social justice. Action, Criticism, and Theory for Music Education 16 (3): 129-47. doi:10.22176/act16.3.129 
Tiainen, Heli, Maami Heikkinen, Kaija Kontunen, Anna-Elina Lavaste, Leif Nysten, Marja-Leena Seilo, Carita Välitalo, and Esko Korkeakoski. 2012. Taiteen perusopetuksen opetussuunnitelmien perusteiden ja pedagogiikan toimivuus. Jyväskylä: Koulutuksen arviointineuvoston julkaisuja 57.

Tulevaisuusvaliokunta. 2014. Mahdollistava valtio - kokeileva Suomi. Tulevaisuusvaliokunnan mietintö 1/20/2014 vp. Helsinki: Eduskunnan tulevaisuusvaliokunnan julkaisuja 6/2014.

Vismanen, Elina, Petteri Räisänen, and Reeta Sariola. 2016. Taiteen perusopetuksen tila ja kehitys 2016. Helsinki: Helsingin kulttuurikeskus.

Väkevä, Lauri. 2015. Music for all? Justifying the two-track ideology of Finnish music education. In Critical music historiography: Probing canons, ideologies and institutions, edited by Vesa Kurkela and Markus Mantere, 45-56. London: Routledge.

Weick, Karl E. 1995. Sensemaking in organizations. Thousand Oaks: Sage.

Wright, Ruth. 2015. Music education and social reproduction: Breaking cycles of injustice. In The Oxford handbook of social justice in music education, edited by Cathy Benedict, Patrick Schmidt, Gary Spruce, and Paul Woodford, 340-56. New York: Oxford University Press.

\section{Notes}

${ }^{1}$ In line with Hordjiik (2007) by "systems analysis" we mean a "problem solving process in which many people take part" that aims "to help ... decision makers and ... policymakers resolve the problems that they face in the short, medium, and long term." Systems analysis is "inherently multi- and interdisciplinary" and can use both quantitative and qualitative approaches.

2 In both syllabi, the calculatory length of a lesson is 45 mins. The advanced syllabus is divided to basic level (635 lessons) and music institute level (635 lessons). Both syllabi should be organized flexibly in order to "take into account the age of the pupil, the acquired skills and knowledge, and the teaching methods used" (Opetushallitus 2002, 8; 2005, 3). This also means that the length of the studies may vary in years from student to student.

3 One can perhaps get at least a partial picture of how popular subject music is in BEA by comparing this amount to the total amount of 0-14 years olds in Finnish population in 2007, which was 894590 . Even if BEA is not exclusively targeted to minors, children (including preschoolers) and teenagers make up the dominant age group participating in it. 